\title{
В. Андріснко
}

Р. Кобко

\section{Andriienko}

R. Kobko

\section{РОЛЬ ДЕРЖАВНОГО РЕГУЛЮВАННЯ У ПРОЦЕСІ ЗАБЕЗПЕЧЕННЯ ЕКОНОМІЧНОЇ БЕЗПЕКИ РИНКУ СТРАХОВИХ ПОСЛУГ УКРАЇНИ}

\author{
THE ROLE OF GOVERNMENT REGULATION IN THE PROCESS OF ENSURING \\ ECONOMIC SECURITY OF INSURANCE MARKET IN UKRAINE
}

У статті проаналізовано вплив державного регулювання на економічну безпеку страхового ринку України в умовах розвитку економіки. Проаналізовано основні складові забезпечення економічної безпеки та механізми державного регулювання страхового ринку. Зокрема досліджено певні відмінності в законодавчих актах, на базі яких здійснюється державне регулювання страхового ринку в Україні, динаміку та структуру активів, а також страхових резервів страховиків у контексті забезпечення платоспроможності страхових компаній, в результаті - ринку страхування в цілому. Досліджено перестрахування як вагомий інструмент економічної безпеки страхового ринку. Проаналізовано основні загрози економічній безпеиі страхового ринку та індикатори таких загроз. Крім того, проведений аналіз засвідчив вагомий вплив державного регулювання на економічну безпеку страхового ринку України. Особлива увага зосереджена на ідентифікації зовнішніх загроз та формуванні превентивних заходів щодо їх попередження. У ході дослідження доведено, щзо в сучасних умовах розвитку економіки завданнями державного регулятора у напрямі створення для вітчизняного ринку страхування безпечного середовища є зміна орієнтованості капіталізації страховиків і якості їх активів, підвищення вимог до вітчизняних перестрахових компаній $i$ перестраховиківнерезидентів, уведення обов'язкового розміщення коштів страхових резервів у вигляді державних цінних паперів як таких, що дають високу ставку дохідності. Проаналізовано типові шахрайські діі, які спостерігаються на вітчизняному страховому ринку. Досліджено вплив фінансової глобалізаиії на економічну безпеку. Тим більще, досліджено заходи, що мають суттсво вплинути на підвищення економічної безпеки у сфері страхування $і$ як наслідок - безумовне виконання страховиками взятих на себе зобов'язань і відновлення довіри суспільства.

Ключові слова: страховий ринок, економічна безпека, загрози економічній безпеці, державне регулювання страхового ринку, інструменти державного регулювання страхового ринку, шахрайські дії.

Постановка проблеми. Економічна безпека страхового ринку, як і його розвиток в цілому, значною мірою залежить від ефективності форм та методів державного регулювання. Від безпечного розвитку страхового ринку та фінансового забезпечення страхових компаній залежить розвиток усіх секторів вітчизняної економіки.

Особлива роль у забезпеченні економічної безпеки страхового ринку відводиться ідентифікації загроз та здійсненню комплексу заходів щодо їх попередження. Важливе значення для підтримки оптимального рівня економічної безпеки має протидія шахрайським проявам на страховому ринку. 3 огляду на це, є актуальним дослідження ролі безпосередньо держави у процесі забезпечення економічної безпеки ринку страхових послуг України.

Аналіз останніх досліджень і публікацій. Державне регулювання страхового ринку в різних його аспектах розглядається у працях багатьох вітчизняних науковців, зокрема Базилевича В., Внукової Н., Вовчак О., Гаманкової О., Філонюка О., Осадця С., Слюсаренко О., Адамович А., Пластун В. та ін.

Формулювання цілей статті. Метою статті є оцінка ролі державного регулювання у процесі забезпечення економічної безпеки ринку страхових послуг України.

Виклад основного матеріалу дослідження. Основними ознаками сучасного етапу розвитку світової економіки є лібералізація зовнішньоекономічних відносин, посилення інтеграційних та глобалізаційних процесів на міжнародних фінансових та товарних ринках, що відбувається завдяки відкритості національних економік та співпраці країн у різних сферах господарської діяльності.

Проте, відкритість національної економіки, з одного боку, сприяє розвитку та поглибленню економічних, виробничих, фінансових, соціальних, культурних та інших взаємовідносин між країнам. 
3 іншого боку, це робить економіку держави більш уразливою до дії дестабілізуючих чинників релевантного зовнішнього середовища, турбулентності міжнародних фінансових і товарних ринків та загроз політичного і соціального характеру.

Зокрема, економічна безпека ринку страхових послуг залежить від багатьох чинників, як внутрішніх, так і зовнішніх, об'єктивних та суб'єктивних. Основними з-поміж них є стан розвитку ринку страхових послуг, фінансова результативність та ефективність діяльності страхових компаній, з одного боку, та реальний стан суб'єктів господарювання - 3 іншого [1].

Роль страхового ринку в забезпеченні економічної безпеки держави в цілому відзначається у працях багатьох вітчизняних дослідників. Як окрему складову в системі забезпечення економічної безпеки держави його виокремлюють такі науковці, як Барановський О. I., Геєць В. М., Теліженко О. М. та ін.

Таким чином, узагальнюючи науково-методичні підходи до розуміння сутності економічної безпеки держави та ідентифікації місця безпеки страхового ринку в іiї структурі, можна подати схематично (рис. 1).

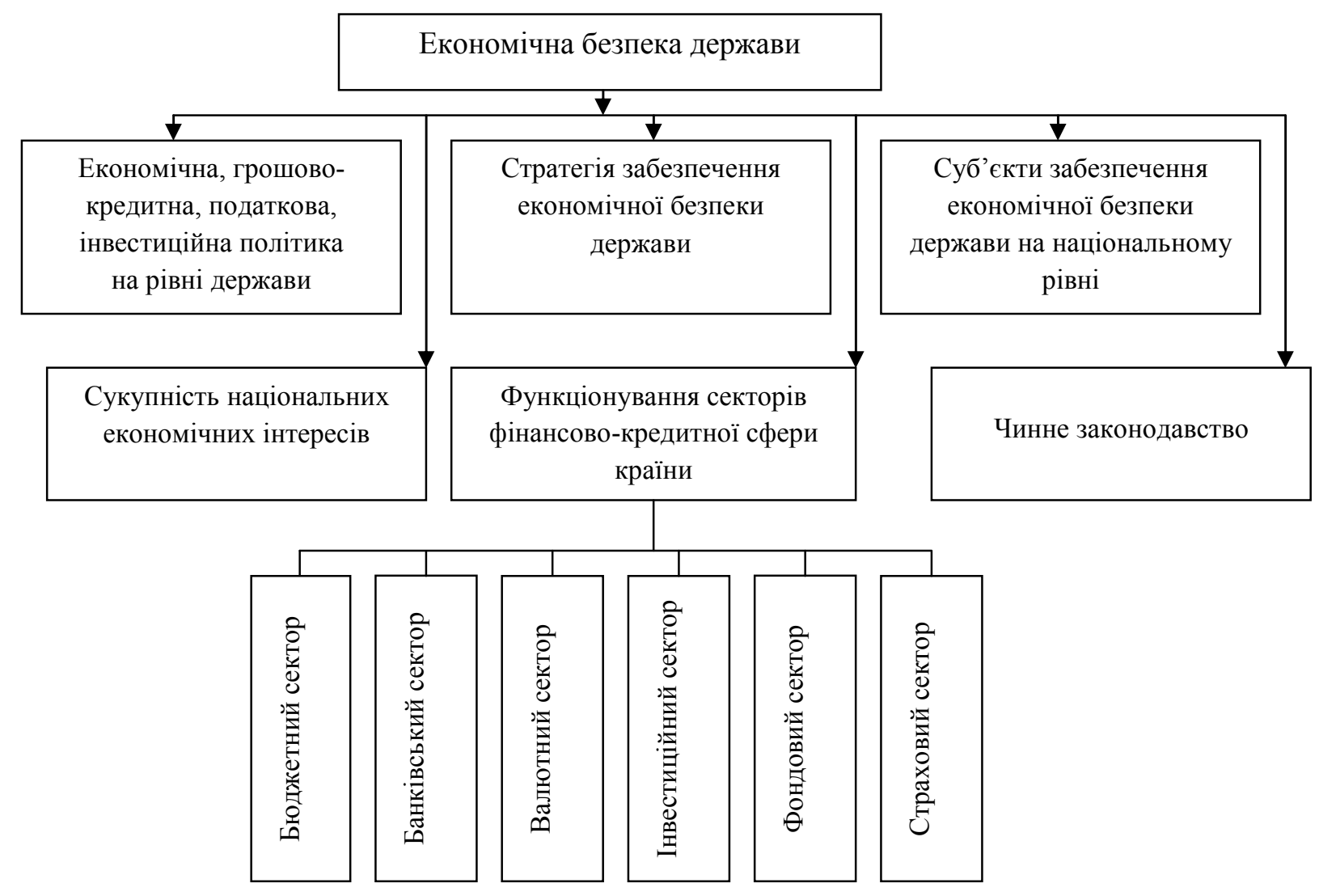

Джерело: [9].

Рис. 1. Складові забезпечення економічної безпеки держави

Таким чином, на сучасному етапі розвитку економічних відносин виконання завдання щодо підтримки економічної безпеки держави неможливе без забезпечення стійкого та ефективного функціонування іiі страхового ринку.

В умовах зростання впливу тенденцій світового фінансового ринку на функціонування національних страхових ринків посилюється необхідність здійснення державних заходів щодо підтримки економічної безпеки страхового ринку. Водночас одним із наслідків глобалізації у фінансовій сфері стало зменшення можливостей державних регулюючих органів контролювати економічні операції та впливати на економічні процеси в державі. Незважаючи на це, здійснення державного регулювання страхового ринку є не лише важливим, а й необхідним, особливо в контексті забезпечення економічної безпеки страхового ринку, а через нього - i економічної безпеки держави.

Важливе місце в системі державного регулювання страхової діяльності посідають також адміністративні та економічні важелі впливу. Що стосується економічних інструментів регулювання, то 
ïx сутність полягає у створенні таких економічних умов, які б забезпечували вибір страховими компаніями тих напрямів функціонування, які б були вигідними та необхідними для суспільства. Економічні засоби впливу застосовуються в рамках непрямих методів регулювання страховою діяльністю і містять інструменти грошово-кредитної, податкової, бюджетної політики та інших складових економічної політики держави [2].

Адміністративні інструменти державного регулювання страхової діяльності належать до системи прямого регулювання та характеризуються безальтернативністю вибору варіантів вирішення певних завдань, обов'язковістю дотримання поставлених вимог та відповідальністю суб'єктів за ухилення від виконання розпоряджень і наказів. Слід зазначити, що групи економічних та адміністративних інструментів регулювання досить тісно взаємопов'язані і часто доповнюють одне одного.

Таким чином, механізм державного регулювання страхового ринку - це сукупність форм, методів та інструментів регуляторного впливу, за допомогою яких здійснюється регулювання і контроль страхової діяльності, а також забезпечується захист прав та економічних інтересів суб'єктів страхового ринку (рис. 2).

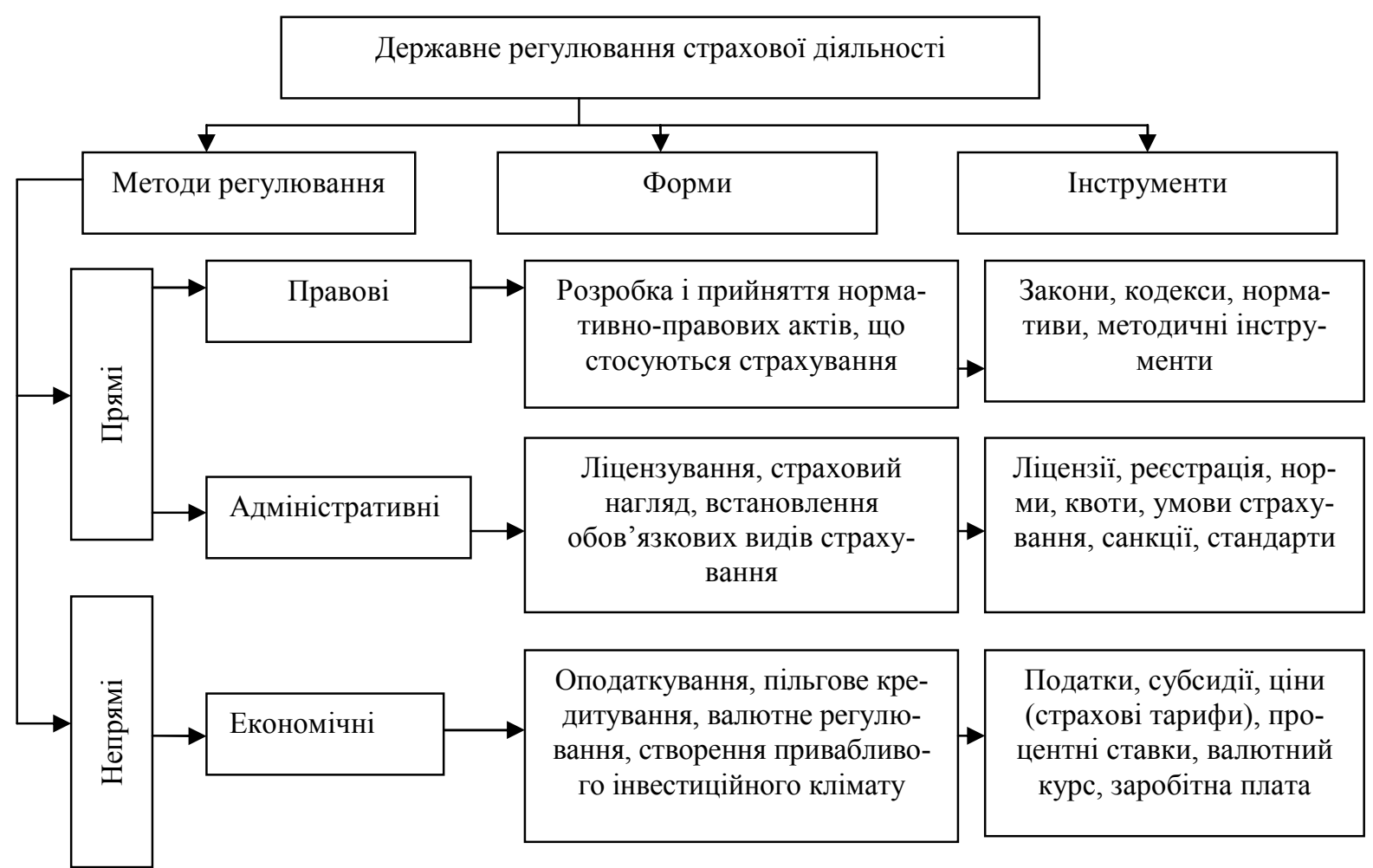

Джерело: [4].

Рис. 2. Механізми державного регулювання страхового ринку

Таким чином, поєднання методів та інструментів державного регулювання страхової діяльності, що застосовуються в країні, має максимально враховувати рівень розвитку національного ринку фінансових послуг та рівень його інтеграції у світову економічну систему, а також загальні особливості економічних та соціальних процесів у країні. Адже сьогодні рівень економічної безпеки страхового ринку є важливим індикатором розвитку страхового ринку, економічної системи та в цілому держави, який являє собою нереалізовану, проте реальну загрозу певного збитку суб'єктам господарювання (рис. 3).

Таким чином, для сучасного етапу розвитку світового господарства дедалі актуальнішими стають банкрутства всесвітньовідомих компаній або виникнення труднощів у їх діяльності, валютні та боргові кризи, обвали на фондових ринках розвинутих країн світу. Унаслідок того, що на вітчизняному страховому ринку сконцентрований значний за обсягом іноземний капітал, то ймовірність спалаху фінансових криз у нашій країні є доволі значною.

Важливим завданням страхових компаній у рамках забезпечення економічної безпеки страхового ринку є формування збалансованих страхових портфелів, тобто необхідність залишатися економічно стійкими навіть при настанні значних за розмірами збитків. Проблемою вітчизняного страхо- 
вого ринку є те, що більшість страхових компаній відшкодовують витрати за рахунок нових страхових премій, не приділяючи значної уваги формуванню адекватних взятому зобов'язанню страхових резервів [4].

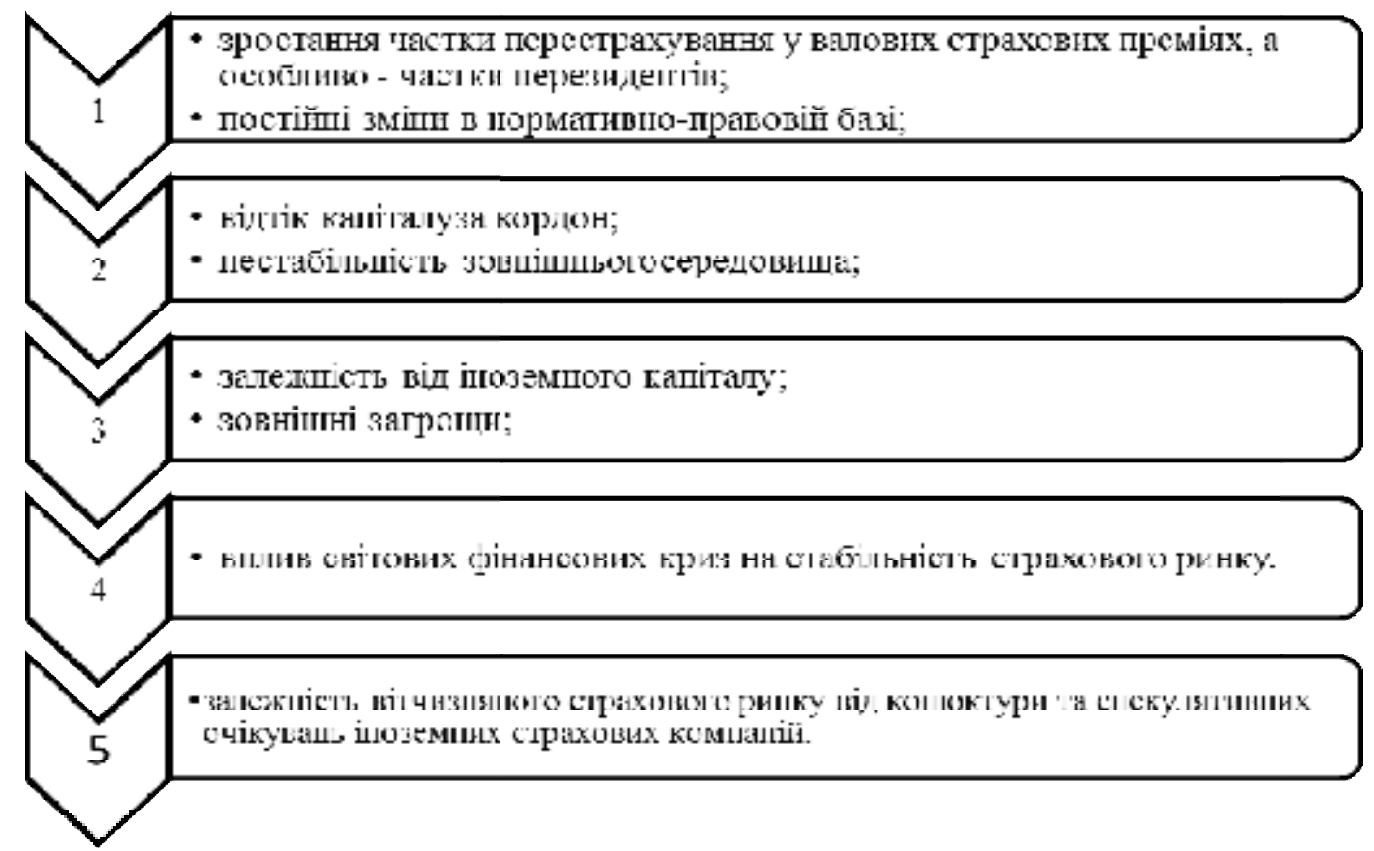

Рис. 3. Основні загрози, які виникають у процесі забезпечення економічної безпеки ринку страхових послуг

Джерело: складено автором на основі [3].

Зазначимо, що загрози, викликані стрімким розвитком глобалізації, у сукупності можуть порушити як економічну безпеку страхового ринку зокрема так і держави в цілому.

При розгляді можливих небезпек економічній безпеці страхового ринку слід звернути увагу на можливі шахрайські дії з боку суб'єктів страхового ринку та необхідність розробки ефективних програм боротьби з легалізації доходів, отриманих злочинним шляхом. Шахрайство в страховому секторі має масштабний характер і набирає з кожним роком все більших обертів. При цьому злочинні дії на страховому ринку в більшості випадків направлені на максимізацію прибутку або на отримання доходу, який не буде підлягати оподаткуванню. Зокрема, страхові компанії вдаються до противоправних дій для зменшення розміру страхового відшкодування, їх працівники - для отримання власної економічної винагороди. Найбільш розповсюджені схеми економічних махінацій на страховому ринку наведено в табл. 1.

Фінансові аналітики оцінюють щорічні сумарні збитки від здійснення шахрайських дій на вітчизняному страховому ринку на рівні 600 млн. грн. Підраховано, що близько $16 \%$ страхових виплат потрапляють до рук фінансових аферистів. Зацікавленість у здійсненні протиправних дій економічними суб' єктами на страховому ринку зумовлена тенденцією динамічного розвитку страхового сектору, недосконалою системою державного регулювання та специфікою страхової діяльності [5].

\section{Можливі шахрайські дії на страховому ринку}

Таблиця 1

\begin{tabular}{|c|l|}
\hline \multicolumn{2}{|c|}{ Загрози економічній безпеці страхового ринку } \\
\hline \multirow{3}{*}{$\begin{array}{c}\text { Страховики } \\
\text { та страхові } \\
\text { посередники }\end{array}$} & $\begin{array}{l}\text { здійснення страхової діяльності компанією без ліцензії на провадження да- } \\
\text { ного виду діяльності; }\end{array}$ \\
\cline { 2 - 2 } & $\begin{array}{l}\text { функціонування незареєстрованих страхових агентів, які укладають договори } \\
\text { від імені страхових компаній; }\end{array}$ \\
\cline { 2 - 2 } & видача фіктивних договорів страхування; \\
\cline { 2 - 2 } & $\begin{array}{l}\text { розробка поліса страхування таким чином, щоб максимально можливим чи- } \\
\text { ном зменшити факт виплати страхового відшкодування; }\end{array}$ \\
\cline { 2 - 2 } & страхування вже зруйнованих об'єктів страховими агентами. \\
\hline
\end{tabular}


Продовження табл. 1

\begin{tabular}{|c|c|}
\hline \multirow{5}{*}{ Страхувальники } & декларування страхової суми, вищої за дійсну вартість об’єкта страхування; \\
\hline & $\begin{array}{l}\text { приховування інформації, що суттєвим чином впливає на рівень страхового } \\
\text { ризику та відповідно впливає на розмір страхової премії; }\end{array}$ \\
\hline & страхування об’єкта страхування одночасно в декількох страхових компаніях; \\
\hline & фальсифікація факту настання страхового випадку; \\
\hline & $\begin{array}{l}\text { навмисне пошкодження або знищення об’єкта страхування, що сприяють } \\
\text { настанню страхового випадку. }\end{array}$ \\
\hline \multirow{5}{*}{$\begin{array}{c}\text { Працівники } \\
\text { страхових } \\
\text { компаній }\end{array}$} & складання страхових полісів з неправдивими даними; \\
\hline & повне або часткове привласнення коштів страхувальників; \\
\hline & перетворення незастрахованих збитків на застраховані; \\
\hline & подання фальсифікованої інформації про страховий випадок; \\
\hline & перегляд розміру страхової суми. \\
\hline
\end{tabular}

Джерело: складено автором на основі [11].

На сьогодні державне регулювання страхового ринку залишається найбільш дієвим та найважливішим механізмом контролю ефективності функціонування страхових компаній та забезпечення економічної безпеки страхового ринку. Крім того, об'єктивна необхідність державного регулювання страхової діяльності в Україні зумовлюється також такими чинниками:

- неефективність конкуренції в страховій галузі внаслідок недостатньої капіталізації більшості вітчизняних страхових компаній та їх неспроможності брати на страхування великі ризики;

- суспільний або змішаний (квазісуспільний) характер ряду страхових послуг, що передбачає суспільну корисність цих послуг, значно вищу за індивідуальну;

- потреба в запровадженні обов'язкових видів страхування за тими видами ризиків, які є невигідними для приватних страховиків внаслідок їх катастрофічного характеру або кумуляції ризиків;

- необхідність урегулювання негативних екстернальних ефектів, пов'язаних з виникненням техногенних аварій, ядерних конфліктів тощо;

- забезпечення прозорості функціонування страхового ринку, законності діяльності страхових компаній та підтримка інформаційної відкритості ринку [6].

Тому, варто більш детальніше дослідити нормативні акти, якими керуються страхові компанії у своїй діяльності.

Основними законодавчими актами, на основі яких здійснюється державне регулювання сфери страхування в Україні, є Закон України «Про фінансові послуги та державне регулювання ринків фінансових послуг» [7] та Закон України «Про страхування» [8]. Так, у відповідності до Закону України «Про фінансові послуги та державне регулювання ринків фінансових послуг» державне регулювання (ринків фінансових послуг, в т. ч. страхового ринку) полягає у «...здійсненні державою комплексу заходів щодо регулювання та нагляду за ринками фінансових послуг 3 метою захисту інтересів споживачів фінансових послуг та запобігання кризовим явищам»

Тобто, вважається, що державне регулювання включає власне регулювання, а також нагляд. У Законі України «Про страхування» йдеться уже не про державне регулювання, а про «державний нагляд за страховою діяльністю». Тобто «державне регулювання» замінено на «нагляд», а «страховий ринок» на «страхову діяльність». Для усвідомлення деяких розбіжностей у цих двох законодавчих актах стосовно поняття державного регулювання та його форм, нагляду за страховою діяльністю, а також функцій державного регулятора (табл. 2).

Сьогодні деякі із вітчизняних науковців, зокрема Гаманкова О. та Філонюк О., вважають, що необхідно розрізняти поняття «державне регулювання страхового ринку», «державне регулювання страхової діяльності», «державне регулювання страхових організації» та «державний страховий нагляд». Із цим не можна не погодитись, тим більше, що і державне регулювання, i державний страховий нагляд здатні суттєво вплинути на безпеку ринку страхування та зростання довіри до нього з боку громадян та підприємств (рис. 4).

Серед інструментів впливу на економічну безпеку національного страхового ринку важливе місце посідає державне регулювання операцій перестрахування, адже саме перестрахування виступає важливим фінансовим інструментом підтримання економічної стабільності страхових компаній неза- 
лежно від розміру їх статутного капіталу, страхових резервів та інших активів. Слід зазначити, що перестрахування в Україні жорстко регламентується державою, в т. ч. перестрахування у нерезидентів. Особливе значення в контексті державного регулювання перестрахування має фінансова надійність перестрахових організацій (як вітчизняних, так і зарубіжних).

Таблиця 2

Порівняльна характеристика розбіжностей в основних законодавчих актах, на основі яких здійснюється державне регулювання страхового ринку в Україні

\begin{tabular}{|c|c|}
\hline $\begin{array}{c}\text { Закон України «Про фінансові } \\
\text { послуги та державне регулювання } \\
\text { ринків фінансових послуг» } \\
\text { від 07.03.1996 p. } \\
\end{array}$ & $\begin{array}{c}\text { Закон України «Про страхування» } \\
\text { від 12.07.2001 p. }\end{array}$ \\
\hline $\begin{array}{l}\text { Державне регулювання ринків } \\
\text { фінансових послуг }\end{array}$ & Державний нагляд за страховою діяльністю \\
\hline $\begin{array}{l}\text { Форми державного регулювання ринків } \\
\text { фінансових послуг: }\end{array}$ & Функції Нацкомфінпослуг: \\
\hline $\begin{array}{l}\text { 1) ведення державних реєстрів фінансо- } \\
\text { вих установ і реєстрів осіб, які не є фі- } \\
\text { нансовими установами, але мають право } \\
\text { надавати окремі фінансові послуги }\end{array}$ & $\begin{array}{l}\text { ведення єдиного державного реєстру страховиків (пере- } \\
\text { страховиків) та державного реєстру страхових та пере- } \\
\text { страхових брокерів. }\end{array}$ \\
\hline $\begin{array}{l}\text { 2) ліцензування діяльності } 3 \text { надання } \\
\text { фінансових послуг }\end{array}$ & $\begin{array}{l}\text { видача ліцензій страховикам на здійснення страхової } \\
\text { діяльності; видача свідоцтв про включення страхових } \\
\text { та перестрахових брокерів до державного реєстру стра- } \\
\text { хових та перестрахових брокерів. }\end{array}$ \\
\hline $\begin{array}{l}\text { 3)нормативно-правовове регулювання } \\
\text { діяльності фінансових установ }\end{array}$ & $\begin{array}{l}\text { розроблення нормативних та методичних документів; } \\
\text { додержання законодавства об'єднаннями страховиків і } \\
\text { страхових посередників; встановлення правил форму- } \\
\text { вання, обліку і розміщення страхових резервів та пока- } \\
\text { зників звітності. }\end{array}$ \\
\hline $\begin{array}{l}\text { 4) нагляд за діяльністю учасників ринків } \\
\text { фінансових послуг (крім споживачів } \\
\text { фінансових послуг) }\end{array}$ & $\begin{array}{l}\text { проведення перевірок страхових компаній на відповід- } \\
\text { ність виданій ліцензії; проведення перевірки додержан- } \\
\text { ня посередниками законодавства про посередницьку } \\
\text { діяльність у страхуванні та перестрахуванні і достовір- } \\
\text { ності їх звітності; здійснення контролю за платоспро- } \\
\text { можністю страховиків відповідно до взятих ними стра- } \\
\text { хових зобов'язань перед страхувальниками }\end{array}$ \\
\hline \multicolumn{2}{|l|}{$\begin{array}{l}\text { 5)застосування уповноваженими держа- } \\
\text { вними органами заходів впливу }\end{array}$} \\
\hline $\begin{array}{l}\text { 6) проведення інших заходів з держав- } \\
\text { ного регулювання ринків фінансових } \\
\text { послуг }\end{array}$ & $\begin{array}{l}\text { узагальнення практики страхової діяльності і посеред- } \\
\text { ницької діяльності на страховому ринку, розроблення і } \\
\text { подання у встановленому порядку пропозицій щодо } \\
\text { розвитку і вдосконалення законодавства України про } \\
\text { страхову і посередницьку діяльність у страхуванні та } \\
\text { перестрахуванні; забезпечення проведення дослідниць- } \\
\text { ко-методологічної роботи з питань страхової і посеред- } \\
\text { ницької діяльності у страхуванні та перестрахуванні, } \\
\text { підвищення ефективності державного нагляду за стра- } \\
\text { ховою діяльністю. }\end{array}$ \\
\hline
\end{tabular}

Джерело: складено автором на основі $[7,8]$.

Варто виділити заходи економічної безпеки страхового ринку, для того щоб покращити його якісні та кількісні показники:

- обов'язкове розміщення коштів страхових резервів у вигляді державних цінних паперів, як таких, що дають високу ставку доходності і мають високий рівень надійності, з метою забезпечення принципів прибутковості та безпечності. Для компаній сфери ризикового страхування пропонується 
рівень у 15 \% від обсягу резервів (сьогодні нормативу розміщення коштів технічних резервів законодавством не встановлено), для компаній зі спеціалізацією «страхування життя»- 25 \% (на сьогоднішній день законодавчо визначено лише верхню межу такого розміщення, зокрема, не більше $80 \%$ страхових резервів);

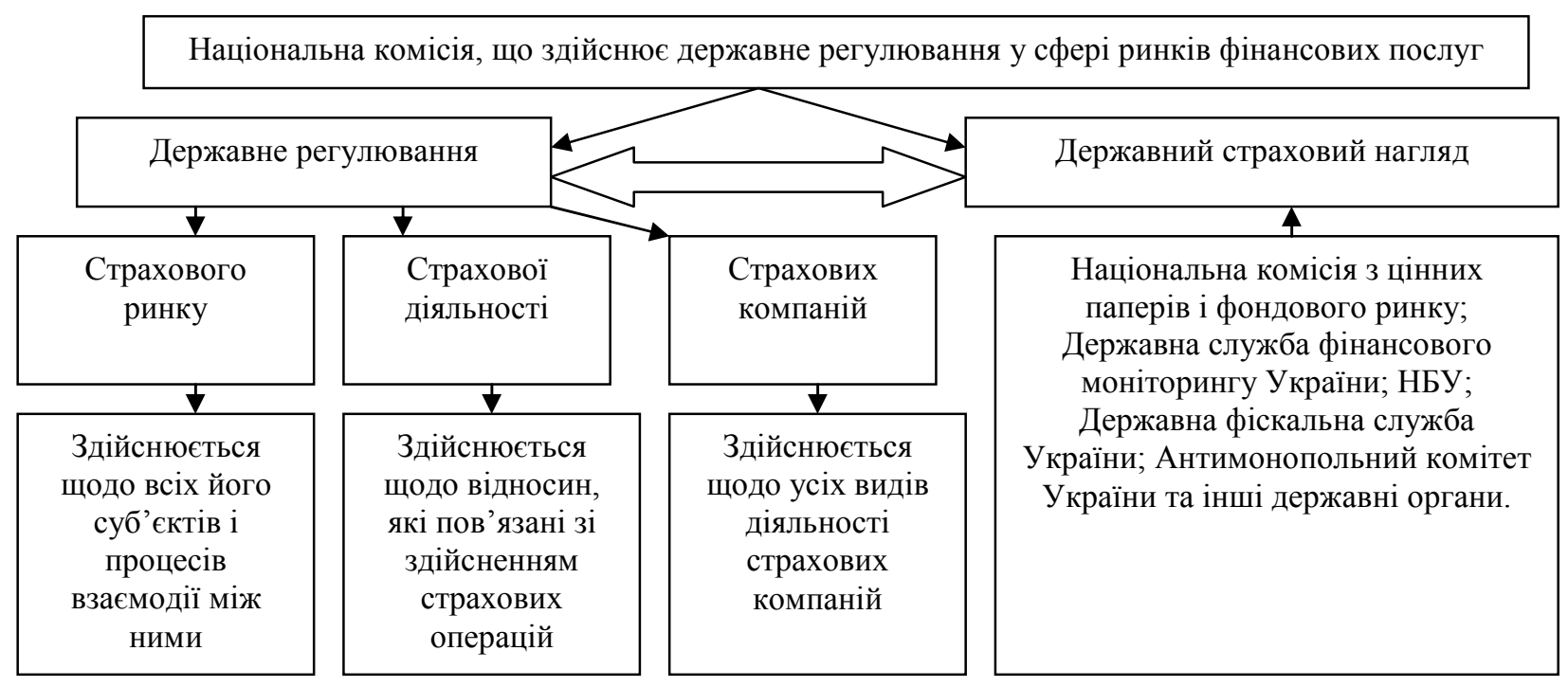

Рис. 4. Взасмозв'язок державного регулювання та державного страхового нагляду в контексті їх впливу на економічну безпеку страхового ринку України

Джерело: складено автором на основі [3].

- рейтинг комерційного банку, в якому можна буде розмістити депозит страховій компанії, має становити «А» та вище за національною рейтинговою шкалою. Внаслідок цього кількість банків України, з якими зможуть співпрацювати вітчизняні страховики, скоротиться приблизно до тридцяти, причому серед цих банків переважатимуть банки з іноземним капіталом, а також увійдуть декілька вітчизняних приватних банків та три державних банки, до яких відсутні претензії з боку НБУ;

- внесення змін до проведення операцій з перестрахування, зокрема встановлення вимоги про наявність досвіду роботи вітчизняного перестраховика не менш як 10 років та високі рейтинги оцінки його платоспроможності за національною шкалою, а також підвищення вимог до перестраховиківнерезидентів, рейтинг яких має бути не менше «А», оскільки світова економічна криза зачепила $\mathrm{i}$ загал міжнародних перестраховиків, які в останні роки працювали в Україні [9].

Таким чином, формування системи державного регулювання страхової діяльності є досить складним процесом, що вимагає проведення значної роботи у сфері законодавчої діяльності, а також потребує вивчення досвіду зарубіжних країн у цій галузі з урахуванням особливостей національного розвитку та наявних проблем і потенційних можливостей вітчизняного страхового ринку.

У зарубіжній практиці склалися різні моделі та типи державного регулювання страхового ринку. Так, за ступенем державного впливу на функціонування страхового ринку розрізняють, як правило, три моделі державного регулювання: жорстку, проміжну та ліберальну.

У свою чергу, залежно від рівня органів державної влади, які наділені повноваженнями щодо регулювання страхового ринку, можна визначити три типи систем страхового регулювання. Найбільш поширеним типом $є$ система регулювання страхового ринку на рівні органів виконавчої влади. Така система застосовується в багатьох розвинених країнах (Японії, Німеччині, Швеції, Великобританії), вона була прийнята також і в Україні.

Інший підхід до формування системи регулювання страхового ринку має дуалістичний характер та передбачає, що деякі аспекти страхової діяльності мають бути врегульовані законодавчо на національному рівні, інші ж основні повноваження, - передаються місцевим органам влади. Така система страхового регулювання діє, наприклад, у Канаді.

Третій тип системи страхового регулювання притаманний федеративним країнам зі значною децентралізацією місцевого самоврядування, зокрема для США. Такий тип регулювання характери- 
зується відсутністю загального національного законодавства у сфері страхування та здійсненням регулювання страхових відносин лише на рівні місцевих органів влади.

Загалом державне регулювання страхової діяльності являє собою систему засобів і методів, здійснюваних на правовій основі $з$ метою визначення рамок і правил функціонування страхового ринку та діяльності страхових компаній на ньому.

Стосовно державної політики стимулювання у сфері страхування, то вона полягає, передусім, у забезпеченні добросовісної конкуренції на страховому ринку, проведенні спеціальної податкової політики, здійсненні пільгового кредитування страхових компаній, створенні сприятливого інвестиційного клімату та встановленні різних пільг для страховиків з метою стимулювання їх діяльності [10].

Крім того, важливою складовою стимулювання розвитку страхового ринку є забезпечення платоспроможності потенційних страхувальників (створення умов для оплати праці й пенсійного забезпечення на належному рівні, для рентабельної діяльності суб’єктів господарювання). Для виконання завдань регулювання страхової діяльності і забезпечення економічної безпеки страхового ринку уповноваженими органами державної влади можуть використовуватися різні методи та інструменти регуляторного впливу.

Як показує світова практика, здійснення правового регулювання страхової діяльності може грунтуватися на двох основних підходах - континентальному та англо-американському. Так, у країнах «континентального» права державне регулювання страхової діяльності базується на жорсткій законодавчій регламентації діяльності суб'єктів страхового ринку. Основними джерелами права при цьому є закони та кодекси. Державне регулювання страхової діяльності в системі «континентального» права здійснюється шляхом встановлення відповідних правових норм щодо:

- затвердження страхових тарифів або встановлення граничних меж їх коливання;

- перевірки виконання бізнес-планів;

- затвердження на державному рівні типових форм страхових договорів;

- нагляду за страховими операціями;

- поточного контролю діяльності страховиків.

До країн, у яких державне регулювання страхової діяльності грунтується на «континентальній» моделі, належать Німеччина, Франція, Італія, Іспанія, Японія.

У свою чергу, у країнах з англо-американською системою права (система загального або прецедентного права) державне регулювання страхової діяльності засновується на прецедентному принципі судового процесу, а не на законодавчих актах як таких. Нормативно-правовими актами в «англоамериканській» системі права визначаються найбільш загальні умови та встановлюються законодавчі обмеження страхової діяльності без детальної регламентації процесу надання страхових послуг. Таким чином, характерною ознакою «англо-американського» права $\epsilon$ відсутність жорсткої регламентації страхової діяльності та вільне визначення форм договорів і величини страхового тарифу. Прикладом країн англо-американської системи права є США, Великобританія, Австралія, Канада. Для цих країн характерна ліберальна модель державного регулювання страхової галузі, за якої найбільша увага приділяється контролю фінансового стану страхових компанії, що базується на аналізі офіційної звітності страховиків [11].

Таким чином, поєднання методів та інструментів державного регулювання страхової діяльності, що застосовуються в країні, має максимально враховувати рівень розвитку національного ринку економічних послуг та рівень його інтеграції у світову економічну систему, а також загальні особливості економічних та соціальних процесів у країні.

Проведений аналіз засвідчив вагомий вплив державного регулювання на економічну безпеку страхового ринку України. У сучасних умовах розвитку національної економіки пріоритетними завданнями державного регулятора у напрямі створення для вітчизняного ринку страхування легітимного та безпечного середовища $€$ зміна орієнтованості капіталізації страховиків та якості їх активів, підвищення вимог до вітчизняних перестрахових компаній та перестраховиків-нерезидентів, введення обов'язкового розміщення коштів страхових резервів у вигляді державних цінних паперів, як таких, що дають високу ставку доходності і мають високий рівень надійності. Зазначені заходи повинні суттєво вплинути на підвищення рівня економічної безпеки сфери страхування, і як наслідок - безумовне виконання страховиками взятих на себе зобов'язань та відновлення довіри суспільства до страховиків.

Висновки. Підсумовуючи, відмітимо, що рівень економічної безпеки страхового ринку визначається тим, наскільки ефективно суб'єкти страхового ринку можуть дієво протистояти наявним та 
потенційним загрозам та усувати негативні фактори впливу на функціонування страхового ринку. 3 іншого боку, безпечний розвиток самого страхового сектору в цілому і перестрахового зокрема $є$ досить важливим та в сучасних умовах нестабільного зовнішнього середовища потребує державного впливу. Проте глобалізаційні та інтеграційні процеси світової фінансової системи останніми роками засвідчили недостатність та неспроможність національного державного регулювання адекватно впливати на економічний ринок окремої країни.

Глобальна економіка, як і національна економіка окремої держави, з одного боку, є самостійної системою, здатною до саморегулювання, але, з іншого - зазнає постійного впливу дестабілізуючих чинників та загроз. Якщо раніше державне регулювання було атрибутом виключно національної економіки, то на сучасному етапі розвитку світової фінансової архітектури виникає об'єктивна необхідність у регулюванні розвитку страхового та перестрахового секторів фінансового ринку з метою забезпечення фінансової безпеки на міжрегіональному глобальному (наднаціональному) рівні.

Таким чином, моніторинг факторів, які аналізуються для виявлення реальних та потенційно можливих загроз, дозволяє визначити рівень економічної безпеки страхового ринку зокрема та держави в цілому. Проте проблемою існуючих методик розрахунку рівня фінансової безпеки страхового ринку $є$ їх фрагментарний характер і відсутність системного підходу до вибору індикаторів. У зазначених умовах постає необхідність комплексного дослідження визначеної проблеми та формування єдиного методологічного комплексу щодо забезпечення економічної безпеки страхового ринку.

\section{Список використаної літератури}

1. Жабинець О. Й. Наукове обгрунтування та сутність поняття «фінансово-економічна безпека страхового ринку» / О. Й. Жабинець // Легалізація економіки та протидія корупції в системі економічної безпеки держави : тези доп. учасників міжнар. наук.-практ. конф. (Львів, 31 травня 2013 р.). - Львів : ЛьвДУВ С, 2013. C. $115-118$.

2. Пластун В. Л. Проблеми страхового шахрайства та практика його уникнення / В. Л. Пластун // Економіка: проблеми теорії та практики : зб. наук. пр. Вип. 254 : в 6 т. - Дніпропетровськ : ДНУ, 2009. - Т. 2. - С. 477488.

3. Філонюк О. Ф. Державне регулювання страхової справи в Україні : автореф. дис. ... канд. наук 3 держ. управл. : 25.00.02 / О. Ф. Філонюк. - К. : Нац. акад. держ. упр. при Президентові України, 2010. - 20 с.

4. Гаманкова О. О. Ринок страхових послуг України : теорія, методологія, практика : монографія / О. О. Гаманкова. - К. : КНЕУ, 2009. - 283 с.

5. Адамович В. Залучення іноземного капіталу до сектору страхових послуг України та Польщі : переваги й ризики [Електронний ресурс] / В. Адамович. - Режим доступу : http://soskin.info/ea/2004/6/20040613.html

6. Винников А. С. Банк России и банковская безопасность / А. С. Винников // Регион. - 1997. - № 2. - С. $19-24$.

7. Про фінансові послуги та державне регулювання ринків фінансових послуг : Закон України від 12.07.2001 р. № 2664-III [Електронний ресурс]. - Режим доступу : http://zakon3.rada.gov.ua/laws/show/2664-14

8. Про страхування : Закон України від 07.03.1996 р. № 85/96-ВР [Електронний ресурс]. - Режим доступу : http://zakon2. rada.gov.ua/laws/show/85/96-\%D0\%B2\%D1\%80

9. Єрмошенко М. М. Фінансова складова економічної безпеки : держава і підприємництво : наукова монографія / М. М. Срмошенко, К. С. Гарячева - К. : ВНЗ «Національна академія управління», 2010. - 248 с.

10. Кисельова О. М. Фактори, які впливають на розвиток страхового ринку України/ О. М. Кисельова // Формування ринкових відносин в Україні. - 2007. - № 2. - С. 76-80.

11. Дубина М. В. Фактори впливу на розвиток регіональної системи небанківських фінансово-кредитних посередників / М. В. Дубина // Фінанси України : матеріали XIV Міжнар. наук.-практ. конф., 19-20 трав. 2010 р. : в 7 т. - Д. : Біла К. О., 2010. - Т. 3. - 101 с.

\section{References}

1. Zhabynets'. O. Y. (2013) Naukove obgruntuvannya ta sutnist' ponyattya «finansovo-ekonomichna bezpeka strakhovoho rynku». Lehalizatsiya ekonomiky ta protydiya koruptsiyi v systemi ekonomichnoyi bezpeky derzhavy: tezy dop. uchasnykiv mizhnar. nauk.-prakt. konf. (L'viv, 31 travnya 2013 r.). L'viv: L'vDUV S, s. 115-118.

2. Plastun, V. L. (2009) Problemy strakhovoho shakhraystva ta praktyka yoho unyknennya. Ekonomika: problemy teoriyi ta praktyky: zb. nauk. pr. Vyp. 254 : v 6 t. Dnipropetrovs'k: DNU, t. 2, s. 477-488.

3. Filonyuk, O. F. (2010) Derzhavne rehulyuvannya strakhovoyi spravy v Ukrayini : avtoref. dys. ... kand. nauk z derzh. upravl.: 25.00.02. Kyiv: Nats. akad. derzh. upr. pry Prezydentovi Ukrayiny, $20 \mathrm{~s}$.

4. Hamankova, O. O. (2009) Rynok strakhovykh posluh Ukrayiny: teoriya, metodolohiya, praktyka : monohrafiya. Kyiv: KNEU, 283 s. 
5. Adamovych, V. Zaluchennya inozemnoho kapitalu do sektoru strakhovykh posluh Ukrayiny ta Pol'shchi: perevahy y ryzyky [Elektronnyy resurs]. Rezhym dostupu : http://soskin.info/ea/2004/6/20040613.html

6. Vynnykov, A. S. (1997) Bank Rossiyi i bankovskaya bezopasnost'. Region, No. 2, s. 19-24.

7. Pro finansovi posluhy ta derzhavne rehulyuvannya rynkiv finansovykh posluh: Zakon Ukrayiny vid 12.07.2001 r. No. 2664-III [Elektronnyy resurs]. Rezhym dostupu : http://zakon3.rada.gov.ua/laws/show/2664-14

8. Pro strakhuvannya: Zakon Ukrayiny vid 07.03.1996 r. No. 85/96-VR [Elektronnyy resurs]. Rezhym dostupu: http://zakon2. rada.gov.ua/laws/show/85/96-\%D0\%B2\%D1\%80.

9. Yermoshenko, M. M., Haryacheva K. S. (2010) Finansova skladova ekonomichnoyi bezpeky: derzhava i pidpryyemnytstvo: naukova monohrafiya. Kyiv: VNZ «Natsional'na akademiya upravlinnya», $248 \mathrm{~s}$.

10. Kysel'ova, O. M. (2007) Faktory, yaki vplyvayut' na rozvytok strakhovoho rynku Ukrayiny. Formuvannya rynkovykh vidnosyn v Ukrayini, No. 2, s. 76-80.

11. Dubyna, M. V. (2010) Faktory vplyvu na rozvytok rehional'noyi systemy nebankivs'kykh finansovo-kredytnykh poserednykiv. Finansy Ukrayiny: materialy XIV Mizhnar. nauk.-prakt. konf., 19-20 trav. 2010 r.: v 7 t. D.: Bila K.O., t. 3, 101 s.

\section{Andriienko, R. Kobko \\ THE ROLE OF GOVERNMENT REGULATION IN THE PROCESS OF ENSURING ECONOMIC SECURITY OF INSURANCE MARKET IN UKRAINE}

The article analyzes the impact of government regulation on economic security of insurance market in Ukraine in terms of economic development. The basic components of ensuring economic security and mechanisms of government regulation of insurance market, in particular, differences in the basic legislative acts, on the basis of which government regulation of insurance market in Ukraine is carried out, the dynamics and structure of assets and insurance reserves of insurers in the context of ensuring the solvency of insurance companies, as a result - insurance market as a whole are analyzed.. Reinsurance is studied as an important instrument of economic security of insurance market. The basic threats to economic security and insurance market indicators of such threats are considered. Besides the analysis has shown a significant effect of government regulation on economic security of insurance market of Ukraine. Special attention is focused on identifying external threats and the formation of preventive measures to avoid them. The study proves that in today's economic development the objectives of government regulator towards the creation of the national insurance market for a safe environment are to change the orientation of insurers capitalization and the quality of their assets, to increase demands for domestic reinsurance companies and non-resident reinsurers, to introduce mandatory allocation of funds insurance reserves in the form of government securities as those that provide higher rate of return. Typical frauds observed in domestic insurance market are investigated.. The influence of financial globalization on economic security is shown. Moreover, the measures for significant improvement of economic security of insurance sphere and as a consequence unconditional fulfillment of obligations by insurerss and restoration of public confidence are examined.

Keywords: insurance market, economic security, threats to economic security, government regulation of insurance market, instruments of government regulation of insurance market, frauds. 